\title{
Clostridium homopropionicum sp. nov., a new strict anaerobe growing with 2-, 3-, or 4-hydroxybutyrate
}

\section{Christina Dörner and Bernhard Schink}

Lehrstuhl Mikrobiologie I der Eberhard-Karls-Uniwersität, Auf der Morgenstelle 28, D-7400 Tübingen, Federal Republic of Germany

Received March 28, 1990/Accepted in revised form May 21, 1990

\begin{abstract}
From anoxic sewage sludge a new strictly anaerobic, spore-forming bacterium was isolated with 2-bydroxybutyrate as sole substrate 2-, 3-, and 4-hydroxybutyrate, 4-chlorobutyrate, crotonate, vinylacetate, and pyruvate were fermented to acetate and butyrate. Fructose was converted to acelate, butyrate, butanol, and $\mathrm{H}_{2}$. Lactate and acrylate were fermented to acetate and propionate. Cells pregrown with lactate fermented 2hydroxybutyrate to butyrate, propionate and acetate. No inorganic electron acceptors were reduced. The DNA base ratio was $32.0+1.0$ mol \% and was similar to that of Closiridium propionicum, which was determined to be $35.3 \pm 0.5 \mathrm{~mol} \%$. Strain LuHBu1 is described as type strain of a new species, Clostridium homopropionicum sp. nov. Another isolate obtained from marine sediment degraded 2- and 3-hydroxybutyrate to acetate and butyrate and was in some respects similar to the known species Ilyobacter polytropus.
\end{abstract}

Key words: Clostridium homopropionicum sp. nov. Clostridium propionicum - $\alpha$-Dehydration - $\gamma$-Dehydration - Butyrate fermentation - Propionate fermentation - Bioenergetics

Propionate is an important intermediate in anaerobic degradation of organic matter (Zehnder et al. 1982). Its degradation to acetate proceeds via the methylmalonylCoA pathway, both in sulfate-reducing bacteria (Stams et al. 1984) and in methanogenic sediment and sludges (Schink 1985) or enrichment cultures (Koch et al. 1983; Houwen et al. 1987). Recently Tholozan et al. (1988) described a temporary accumulation of butyrate in a propionate-degrading methanogenic enrichment culture. NMR-studies with $\left[1-{ }^{13} \mathrm{C}\right]-,\left[2-{ }^{13} \mathrm{C}\right]-$ and $\left[3-{ }^{13} \mathrm{C}\right]$-propionate revealed that propionate was converted to butyrate by reductive carboxylation, without randomization. Such

Offprint requests to: C. Dörner a pathway was not compatible with the concepts of anaerobic propionate metabolism existing so far. In at attempt to isolate bacteria able to catalyze interconversions of propionate and butyrate, we chose 2-hydroxybutyrate and 2-aminobutyrate as enrichment substrates.

\section{Materials and methods}

\section{Sources of organisms}

Enrichment cultures were inoculated with several different sediment and sludge samples of freshwater and marine origin. Strain LuHBu1 was isolated from anoxic digested sludge of the municipal sewage plant in Tübingen, Lustnau, FRG. Strain FMHBu1 was isolated from anoxic sediment of a channel near the fish market in Venice, Italy. Escherichia coli $\mathrm{K} 12$ (DSM 498), Propionibacterium freudenreichii subsp. shermanii (DSM 20270) and Clostridium propionicum (DSM 1682) were obtained from the Deutsche Sammlung für Mikroorganismen, Braunschweig, FRG. Methanospirillum hungatei SK was kindly provided by Dr. F. Widdel, Marburg, FRG.

\section{Media and growth conditions}

Carbonate-buffered, sulfide-reduced mineral medium was prepared as previously described (Widdel and Pfennig 1981). It contained 7-vitamin solution (Widdel and Pfennig 1981), selenite-tungstate solution (Tschech and Pfennig 1984) and the trace element solution SL 10 (Widdel et al 1983). The final $\mathrm{pH}$ of the medium was adjusted to $7.2-7.4$. Freshwater medium contained $0.1 \% \mathrm{NaCl}$ and $0.04 \%$ $\mathrm{MgCl}_{2} \times 6 \mathrm{H}_{2} \mathrm{O}$ whereas salt water medium contained $2 \% \mathrm{NaCl}$ and $0.3 \% \mathrm{MgCl}_{2} \times 6 \mathrm{H}_{2} \mathrm{O}$. The growth temperature was $28^{\circ}-30^{\circ} \mathrm{C}$. Growth was determined by measuring turbidity in a Bausch and Lomb Spectronic 70 spectrophotometer in $22 \mathrm{ml}$ screw-cap tubes. Substrates were added from sterile, neutralized stock solutions.

\section{Isolation and characterization}

For isolation of pure cultures, the agar shake culture method (Pfennig 1978) was applied. Purity was checked microscopically and by growth tests in a medium containing $5 \mathrm{mM}$ lumarate, $3 \mathrm{mM}$ g ${ }^{\dagger}$ ucose, $0.1 \%$ yeast extract, and $10 \mathrm{mM}$ 2-hydroxybutyrate. The Gram type 
was determined according to Bartholomew (1962) and to Gregersen (1978) with Propionibacterium freudenreichii and Escherichia coli as controls. Flagella staining was carried out according to Blenden and Goldberg (1965). For detection of cytochromes, crude cell cxtracts of fructose-grown ceils were prepared by fourtime passage through a French Pressure Cell Press (AMINCO, Silver Spring, USA) at $6.9 \mathrm{MPa}$. Cell debris was removed by centrifugation for $20 \mathrm{~min}$ at $20,000 \times g$. Redox difference spectra (dithionite-reduced minus air-oxidized) were measured in crude cell-free extracts with a Uvikon 860 spectrophotometer (Kontron, Zürich, Switzerland). The guanine-plus-cytosine content of the DNA was determined by the thermal denaturation method according to De Ley (1970) after extraction as described by Marmur (1961). Capacity for nitrogen fixation was checked with cells pregrown for four generations in ammoniafree mineral medium with 2-hydroxy butyrate as substrate. Acetylene was injected into the gas phase of the culture vessel to a concentration of $10 \%(v / v)$, and acetylene and ethylene were determined by gas chromatography after incubation at $30^{\circ} \mathrm{C}$ for two days.

\section{Induction experiments}

Dense cell suspensions (OD 2.5) were prepared with cells pregrown with 2-, 3-, or 4-hydroxybutyrate or lactate in $100 \mathrm{ml}$ infusion bottles (Müller \& Krempel, Bülach, Switzerland), each with $10 \mathrm{mM}$ substrate. Cells were harvested in the late log phase by centrifugation under anaerobic conditions for $30 \mathrm{~min}$ at $4^{\circ} \mathrm{C}$ and $4,500 \mathrm{rpm}$ in a Sorvall RC-5 centrifuge. The pellet was washed once with freshwater medium, and the suspension was distributed anoxically at $10 \mathrm{ml}$ each to $20 \mathrm{ml}$ tubes under $\mathrm{N}_{2} / \mathrm{CO}_{2}(90 \% / 10 \%)$ gas mixture. The tubes received 2-, 3-, 4-hydroxybuityrate, or lactate at $20 \mathrm{mM}$ concentration. Parallel assays contained the respective substrate plus chloramphenicol ( $30 \mathrm{mg} / 1$ ). Product formation was determined by gas chromatography.

\section{Enzyme assays}

Assays were performed with crude cell-free extracts of fructoseor lactate-grown cells of strain LuHBu1 using a Hitachi 100-40 spectrophotometer (Hitachi, Tokyo, Japan). Phosphate acetyl transferase and acetate kinase were measured by standard methods (Bergmeyer 1974). Lactate dehydrogenase was measured with reduced Nicotinamide adenine dinucleotide as electron donor (Bergmeyer 1974) or dichlorophenol indophenol as electron acceptor (Molinari and Lara 1960).

\section{Chemical analyses}

Fatty acids and butanol were assayed by gas chromalography as described (Platen and Schink 1987). For analysis of propionate and butyrate, operation conditions were as follows: $1 \mathrm{~min}$ at $120^{\circ} \mathrm{C}$, $25^{\circ} \mathrm{C} / \mathrm{min}$ to $170^{\circ} \mathrm{C}, 1 \mathrm{~min}$ at $170^{\circ} \mathrm{C}$. Hydrogen was determined by gas chromatography as previously deseribed (Matthies et al. 1989). Acetylene and ethylene were determined with a Carlo Erba GC 6000 gas chromatograph (Mlano, Italy) with flame ionization detector. A glas column ( $2 \mathrm{~m} \times 2 \mathrm{~mm}$ ) was packed with a molecular sieve ( $5 \AA, 18-50$ mesh, Merck, Darmstad1, FRG), column temperature was $140^{\circ} \mathrm{C}$, detector and injector temperature $200^{\circ} \mathrm{C}$. Sulfide formation from sulfate or sulfur was analyzed qualitatively by a rapid detection test (Cord-Ruwisch 1985), nitrite formation from nitrate with sulfanilic acid and $\alpha$-naphthylamine (Procházková 1959). Determination of poly- $\beta$-hydroxybutyrate as storage material was carried out according to Law and Slepecky (1961). Polyphosphates were detected as described by Drews (1983). Protein was quantified by a modified microbiuret method (Zamenhoff 1957).

\section{Chemicals}

All chemicals were of reagent grade quality and obtaincd from Fluka, Neu-Ulm; Merck, Darmstadt; Sigma, Deisenhofen, FRG; and Aldrich, Steinheim, FRG. Gases were obtained from MesserGriesheim, Darmstadt, FRG.

\section{Results}

\section{Enrichment and isolation}

$50 \mathrm{ml}$ enrichment cultures in either freshwater or saltwater medium with $10 \mathrm{mM}$ 2-hydroxybutyrate or 2-aminobutyrate as substrate were inoculated with $5 \mathrm{ml}$ anoxic mud from various habitats. After three to four weeks of incubation, subcultures with 2-hydroxybutyrate were inoculated with $5 \mathrm{ml}$ culture fiuid. Enrichments with 2-aminobutyrate exhibited slow gas production, but subcultures did not grow. Enrichment of a 2-hydroxybutyrate-degrading bacterium from a propionate-degrading enrichment culture (provided by J. L. Tholozan, Lille, France) failed as well. Butyrate and acetate were the main products formed from 2-hydroxybutyrate; propionate was detected at low concentrations $(0.5 \mathrm{mM})$. After five to six transfers, the cultures contained mainly one single type of bacterium. A long, motile, sporeforming rod prevailed in the freshwater enrichment culture inoculated with sewage sludge, whereas a short, non-motile rod was enriched from marine sediment.

The prevailing bacteria were isolated in two subsequent dilution series with $10 \mathrm{mM}$ 2-hydroxybutyrate and $0.05 \%$ yeast extract, and transferred into liquid mineral medium. Purity was checked by microscopic control after growth in selective or complex test media. Strain FMHBul required $0.05 \%$ yeast extract for growth in pure culture.

\section{Morphology and cytological characterization}

Cells of the marine strain FMHBu1 were short rods with rounded ends, $1.0 \times 2.5-4.5 \mu \mathrm{m}$ in size (Fig. $1 \mathrm{a}$ ). The gram Type after staining and the KOH-test was negative. Treatment with Lugol's potassium iodide-iodine solution (Drews 1983) stained areas at the cell end brown indicating the presence of glycogen-like polysaccharides. Spore formation was never observed. The guanine-pluscytosine content of the DNA was determined to be $64.2 \pm 1.0 \mathrm{~mol} \%$.

Cells of strain LuHBu1 were long, straight rods, 1.2 $1.5 \times 5.5-10 \mu \mathrm{m}$ in size, with rounded ends ( $\mathrm{Fig}, 1 \mathrm{~b}$ ). Heat resistant spherical spores were formed in the terminal to subterminal region (Fig. 1c). Especially with fructose, lactate, or pyruvate, spores were formed very soon after reaching the stationary growth phase. Sporulation mediutn (Hollaus and Sleytr 1972) did not accelerate spore formation. Cells grown with fructose or lactate formed round dark inclusions, probably polyphosphates. Poly- $\beta$-hydroxybutyrate could not be detected. Growing cells were slowly motile but lost motility very soon in 

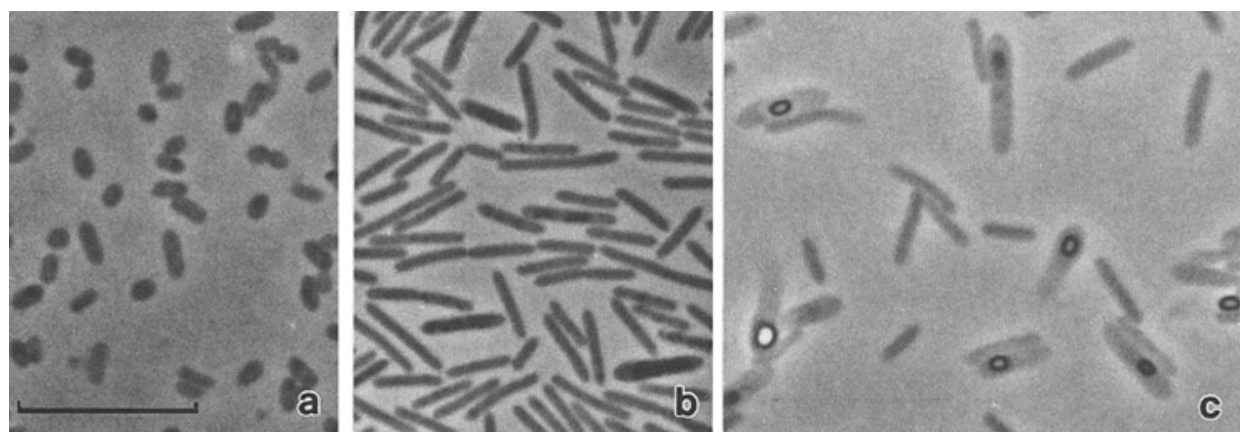

Fig. 1a-c. Phase contrast photomicrograph of 2hydroxybutyrate-utilizing isolates.

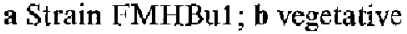
cells of strain LuriBu1; $\mathrm{c}$ spontated cells of strain LuHBul. Bar equals $10 \mu \mathrm{m}$ for all panels ageing cultures. Flagella staining demonstrated $4-6$ peritrichously inserted flagella. Cells stained Gram negative, however, the gram type determined by the $\mathrm{KOH}$ test was positive. The guanine-plus-cylosine content of the DNA was determined to be $32.0 \pm 1.0 \mathrm{~mol} \%$. No cytochromes were detected by redox difference spectroscopy in crude cell extracts of fructose-grown cells.

\section{Physiology and stoichiometry of fermentation}

Both strains were obligately anaerobic. Strain FMHBu1 grew in mineral medium with a least $0.5 \% \mathrm{NaCl}$. Growth was possible in a temperature range between $4^{\circ} \mathrm{C}$ and $32^{\circ} \mathrm{C}$, with an optimum at $28^{\circ} \mathrm{C}$; the $\mathrm{pH}$-range was $6.0-$ 8.5 with an optimum at 7.0. Phosphate concentrations up to $50 \mathrm{mM}$ did not inhibit growth. Neither nitrate, nitrite, nor sulfate, thiosulfate, sulfite, or sulfur was reduced. With 2-hydroxybutyrate as substrate, a growth rate of $0.238 \mathrm{~h}^{-1}\left(t_{\mathrm{d}}=3 \mathrm{~h}\right)$ was reached. Strain FMHBu1 fermented 2- and 3-hydroxybutyrate and crotonate to acetate and butyrate, pyruvate to acetate and $\mathrm{H}_{2}$, and succinate to propionate.

Strain LuHBu1 grew in freshwater and in brackish water medium containing $1 \% \mathrm{NaCl}$ and $0.15 \%$ $\mathrm{MgCl}_{2} \times 6 \mathrm{H}_{2} \mathrm{O}$, but not in saltwater medium. However, growth in brackish water medium was delayed, and cell yields were lower. Phosphate was tolerated at concentrations up to $50 \mathrm{mM}$. Growth was possible at tempera tures between $20^{\circ} \mathrm{C}$ and $40^{\circ} \mathrm{C}$, the optimum was $37^{\circ} \mathrm{C}$; the $\mathrm{pH}$ range was $5.6-8.3$ with an optimum at 7.2. No inorganic electron acceptors such as nitrate, sulfate, thiosulfate, sulfite, or sulfur were reduced. The cells could use molecular nitrogen as sole nitrogen source. The doubling time with $10 \mathrm{mM}$ 2-hydroxybutyrate was $8 \mathrm{~h}$. A growth curve with 2-hydroxybutyrate is presented in Fig. 2. Strain LuHBu1 grew well with 2-, 3-, or 4-hydroxybutyrate, crotonate, vinylacetate, fructose, pyruvate, lactate and, with lower growth rates, also with 4chlorobutyrate and acrylate at low concentrations (2.5 $\mathrm{mM}$ ). Fermentation products of the hydroxybutyrates, 4-chlorobutyrate, vinylacetate, crotonate, and pyruvate were acetate and butyrate. If cells grew in culture vessels with a gas head space also hydrogen was produced from pyruvate.

Fructose was fermented to acetate, butyrate, butanol and $\mathrm{H}_{2}$, while lactate and acrylate were fermented to acetate and propionate. The stoichiometry of substrate

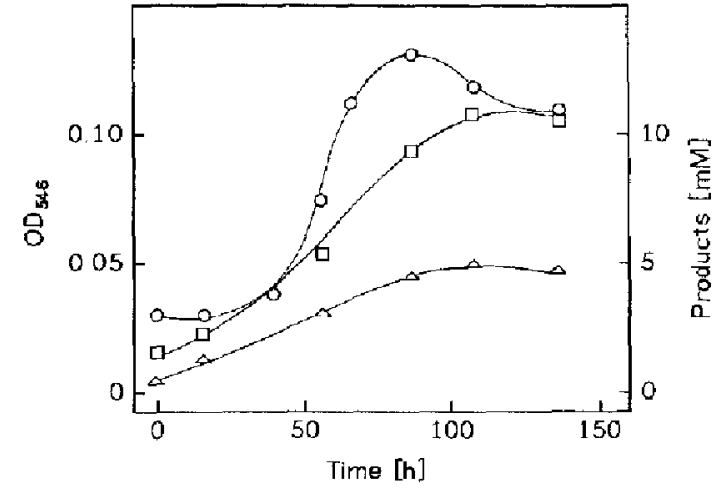

Fig. 2. Time course of growth and product formation by strain LuHBu1 with 2-hydroxybutyrate as substrate. Experiments were carried out in 100-ml serum bottles. OD ${ }_{546}$ : optical density at $546 \mathrm{~nm}$. Symbols: $\bigcirc$ cell density, $\square$ acetate, $\triangle$ butyrate

utilization, product formation, and growth yields are presented in Table 1.

\section{Induction experiments}

To check for possible common step in degradation of the hydroxybutyrate isomers, induction experiments were carried out with strain $\mathrm{LuHBu1}$. The results are summarized in Table 2. 3-hydroxybutyrate was degraded rapidly in all assays, no matter on which substrate cells were pregrown, and chloramphenicol had no effect. Addition of chloramphenicol to 2-hydroxybutyrate-grown cell suspensions inhibited not only degradation of 4-hydroxybutyrate, but also of 2-hydroxybutyratc. Degradation of lactate by lactate-grown cells was slightly inhibited by chloramphenicol. Lactate-pregrown cells fermented 2-hydroxybutyrate to acetate, propionate, and butyrate according to the following fermentation equation:

\section{2-hydroxybutyrate $\rightarrow 8.6$ acetate}

+3.3 propionate +9.1 butyrate.

These cells did not degrade propanol or propionate, neither in pure culture nor in coculture with Methanospirillum hungatei.

\section{Enzyme activities of strain LUHBu1}

Phosphate acetyl transferase (EC 2.3.1.8) activity in fructose-grown cells was $1.13 \mathrm{U} / \mathrm{mg}$ protein. Acetate kinase 
Table 1. Stoichiometry of fermentation and growth yields of strain LuHBul

\begin{tabular}{|c|c|c|c|c|c|c|c|c|c|}
\hline \multirow[t]{2}{*}{ Substrate } & \multirow{2}{*}{$\begin{array}{l}\text { Substrate } \\
\text { added } \\
\text { [umol] }\end{array}$} & \multirow{2}{*}{$\begin{array}{l}\text { Cell dry } \\
\text { mass } \\
\text { formed }^{\mathrm{a}} \\
{[\mathrm{mg}]}\end{array}$} & \multicolumn{5}{|c|}{ Products formed [ $\mu \mathrm{mol}]$} & \multirow{2}{*}{$\begin{array}{l}\text { Electron- } \\
\text { recovery } \\
{[\%]}\end{array}$} & \multirow{2}{*}{$\begin{array}{l}\text { Molar } \\
\text { growth } \\
\text { yield } \\
\text { [g/mol] }\end{array}$} \\
\hline & & & $\begin{array}{l}\text { Ace- } \\
\text { tate }\end{array}$ & $\begin{array}{l}\text { Buty- } \\
\text { rate }\end{array}$ & $\begin{array}{l}\text { Propio- } \\
\text { nate }\end{array}$ & $\begin{array}{l}\text { Bata.. } \\
\text { nol }\end{array}$ & $\mathrm{H}_{2}$ & & \\
\hline 2-Hydroxybutyrate & 200 & 0.73 & 179 & 103 & - & - & n.d, & 98 & 3.65 \\
\hline 3-Hydroxybutyratc & 200 & 0.87 & 184 & 107 & - & - & n.d. & 104 & 4.35 \\
\hline 4-Hydroxybutyratc & 200 & 0.87 & 182 & 90 & - & - & n.d. & 107 & 4.35 \\
\hline 4-Chlorobutyrate & 100 & 0.35 & 94 & 46 & - & - & n.d. & 96 & 3.50 \\
\hline Crotonate & 200 & 0.95 & 203 & 94 & -- & - & n.d. & 102 & 4.75 \\
\hline Vinylacetate & 200 & 0.89 & 190 & 100 & - & - & nd. & 102 & 4.45 \\
\hline Pyruvate & 200 & 1.23 & 109 & 42 & - & - & n.d. & 100 & 6.15 \\
\hline Lactate & 200 & 0.87 & 63 & - & 94 & - & n.d. & 79.5 & 4.35 \\
\hline Acrylate & 50 & 0.22 & 16 & - & 33 & - & n.d. & 104 & 4.40 \\
\hline Fructose & 100 & 0.49 & 73 & 41 & - & 11 & 135 & 103 & 31.20 \\
\hline
\end{tabular}

Expetiments were carried out in $22 \mathrm{ml}$ tubes completely filled with mineral modium, or in $100 \mathrm{ml}$ infusion bottles with head space in case of fructose as substrate.

a Cell dry matter was calculated from turbidity at $546 \mathrm{~nm}$ using the conversion factor $0.1 \mathrm{OD}_{546}=33.0 \mathrm{mg} / 1$, which was obtained by direct determinations in $500 \mathrm{ml}$ cultures grown with fructose

${ }^{b}$ not determined

Tablc 2. Degradation of various substrates by cell suspensions of strain LuHBu1 pregrown with 2-, 3-, 4-hydroxybutyrate, or lactate

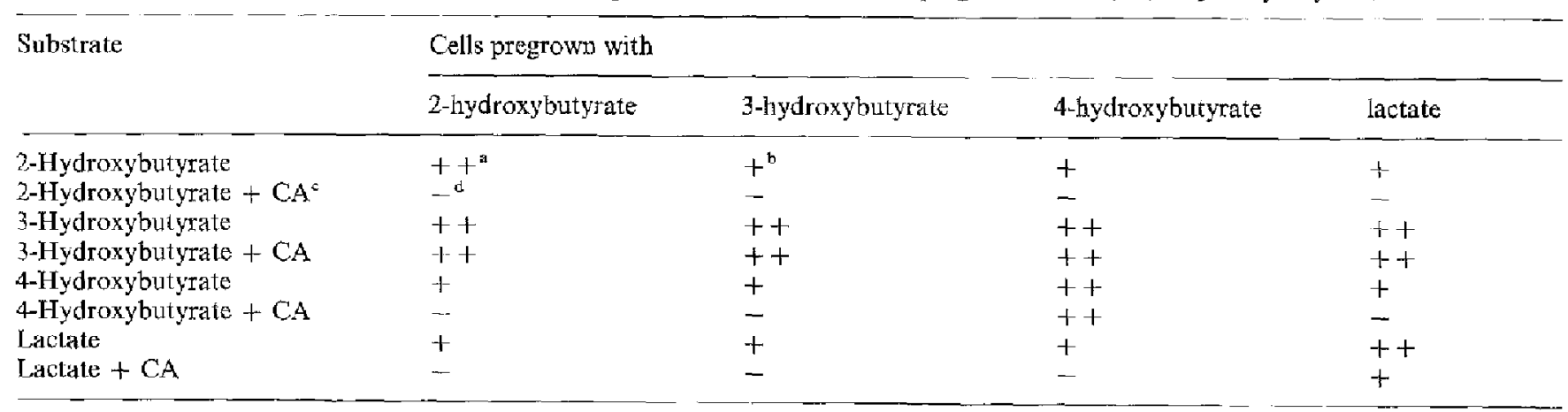

- Rapid legradation within 5 h or less

Delayed degradation starting after $20 \mathrm{~h}$ or more

- Chloramphenicol

a No degradation

(EC 2.7.2.1) was found at $0.56 \mathrm{U} / \mathrm{mg}$ protein. NADindependent lactate dehydrogenase (EC 1.1.2.3) activity was $0.46 \mathrm{U} / \mathrm{mg}$ protein. NAD-dependent lactate-dehydrogenase (EC 1.1.1.27) activity could not be detected.

\section{Discussion}

\section{Physiology}

Two bacterial strains are described in this paper which were isolated with 2-hydroxybutyrate as sole carbon and energy source from anoxic sewage sludge or marine sediment. Strain FMHBu1 fermented 2- and 3-hydroxybutyrate and crotonate to acetate and butyrate, pyruvate to acetate and $\mathrm{H}_{2}$, and succinate to propionate. With these properties, as well as by its cytological characters, it resembles the 3-hydroxybutyrate-fermenting Iyobacter polytropus (Stieb and Schink 1984), however, differs from this strain by its ability to use 2-hydroxybutyrate, and by its comparably high guanine-plus- cytosine content of the DNA $32.2 \pm 0.5 \mathrm{~mol} \%$ for $I$. polytropus, as opposed to $64.2 \pm 1 \mathrm{~mol} \%$ for strain FMHBu1). This strain was not characterized in further detail.

More interesting was the freshwater isolate from sewage sludge, strain LuHBu1. It fermented the isomers 2-, 3-and 4-hydroxybutyrate, as well as 4-chlorobutyrate, crotonate, vinylacetate and pyruvate, to acetate and butyrate. Fructose was converted to acetate, butyrate, traces of butanol, and $\mathrm{H}_{2}$, whereas lactate and acrylate were degraded to acetate and propionate. Induction experiments revealed that 3-hydroxybutyrate was degraded by an enzyme system which was present as well in cells pregrown with either 2-hydroxybutyrate, 4-hydroxybutyratc, or lactate.

Obviously, dismutation of 3-hydroxybutyrate via crotonate to acetate and butyrate plays a central role in the metabolism of this strain (Fig. 3). 2-hydroxybutyrate could enter this pathway by elimination of the 2-bydroxy group, analogous to lactyl-CoA conversion to acrylyl$\mathrm{COA}$ by Clostridium propionicum (Cardon and Barker 


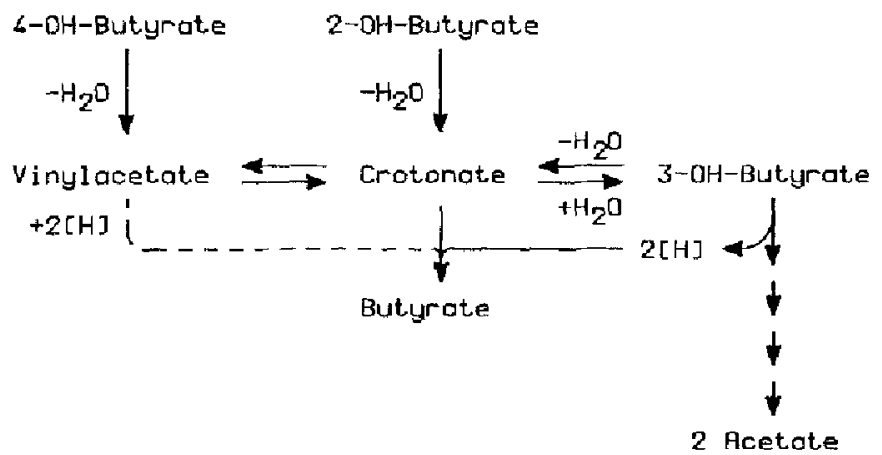

Fig. 3. Hypothetical pathway of fermentation of 2-, 3- and 4-hydroxybutyrate by strain LuHBu1. A possible direct reduction of vinylacetate to butyrate is indicated by the dashed line

1947). The reversible dehydration of 2 -hydroxy acids to 2-enoic acids is of considerable interest in biochemistry since the eliminated hydrogen is not activated and the hydroxyl group is a very poor leaving group. The reaction probably proceeds through a radical mechanism, similar to reversible dehydration of 2-hydroxyglutaryl-CoA to glutaconyl-CoA during glutamate fermentation by Acidarninococcus fermentans (Schweiger and Buckel 1984). This reaction is inhibited by chloramphenicol (Buckel, personal communication) as was observed also for 2-hydroxybutyrate degradation by strain LuHBu1, indicating that similar enzyme systems are involved in these $\alpha$-dehydration reactions. Degradation of 4-hydroxybutyrate or 4-chlorobutyrate poses similar chemical problems. The hydrogen at $C$-atom 3 is not activated and therefore a radical mechanism must be postulated for these elimination reactions, too. Conversion of 4-hydroxybutyrate or 4-chlorobutyrate to butyrate could include a direct reduction of vinylacetate or could require an isomerization of vinylacetate to crotonate, a reaction observed also for $C$. aminobutyricum (Hardman and Stadtman 1963). All these transformations occur probably with the respective coenzyme A-esters as future research will have to elucidate. The results obtained by the induction experiments are summarized in a hypothetical pathway (Fig. 3).

To our surprise, lactate-grown cells in dense suspension converted 2-hydroxybutyrate to butyrate, acetate and considerable amounts of propionate. Obviously, propionate and butyrate are formed from 2-hydroxybutyrate in a similar manner as lactate is fermented to acetate and propionate. Although a net conversion of butyrate to propionate could not be established as was originally intended in this study, it is evident that the enzyme apparatus of strain LuHBu1 can mediate between $\mathrm{C}_{3^{-}}$and $\mathrm{C}_{4}$-compounds.

Strain LuHBu1 also grew with 4-chlorobutyrate as solc energy and carbon source but did not use 3-chlorobutyrate, 3-chloropropionate or 2-chloropropionate as substrate, as described for a recently isolated anaerobic bacterium with a similar fermentation pattern (Matsuda et a1., Abstract, FEMS Symposium on Microbiology and Biochemistry of Strict Anaerobes Involved in Interspecies Hydrogen Transfer, Marseille, France, September 1989).
Strain LuHBu1 degraded the various substrates according to the following fermentation equations (calculations of free energy changes after Thaucr et al. 1977).

$$
\begin{array}{r}
2 \text { hydroxybutyrate } \rightarrow 2 \text { acetate }^{-}+\text {butyrate }^{-}+\mathrm{H}^{+} \\
\Delta \mathrm{G}^{\mathrm{o}^{\prime}}=-59.4 \mathrm{~kJ} / \mathrm{mol} \text { substrate } \\
\left.2 \text { crotonate }^{-} \text {(or vinylacetate }\right)+2 \mathrm{H}_{2} \mathrm{O} \\
\rightarrow 2 \text { acetate }^{-}+\text {butyrate }^{-}+\mathrm{H}^{+} \\
\Delta \mathrm{G}^{\alpha^{\prime}}=-51.1 \mathrm{~kJ} / \mathrm{mol} \text { substrate } \\
14 \text { pyruvate }^{-}+14 \mathrm{H}_{2} \mathrm{O} \rightarrow \\
10 \text { acetate } \\
\rightarrow 10 \mathrm{HCO}_{3}^{-}+3 \text { butyrate } \\
\Delta \mathrm{G}^{-\prime}=-72.4 \mathrm{~kJ} / \mathrm{mol}^{+}
\end{array}
$$

3 lactate

$\rightarrow$ acetate ${ }^{-}+\mathrm{HCO}_{3}^{-}+2$ propionate ${ }^{-}+\mathrm{H}^{+}$

$$
\Delta \mathrm{G}^{\mathrm{a}}=-54.9 \mathrm{~kJ} / \mathrm{mol} \text { substrate }
$$

3 acrylate ${ }^{-}+3 \mathrm{H}_{2} \mathrm{O} \rightarrow$ acctate $^{-}+\mathrm{HCO}_{3}^{-}$

+2 propionate ${ }^{-}+\mathrm{H}^{+}+\mathrm{H}^{+}$

$$
1 \mathrm{G}^{\mathrm{a} \prime}=-49.4 \mathrm{~kJ} / \mathrm{mol} \text { substrate }
$$

fructose $+4 \mathrm{H}_{2} \mathrm{O} \rightarrow 1.3$ acetate $^{-}+0.4$ butyrate $^{-}$

$+2.1 \mathrm{HCO}_{3}^{-}+2.1 \mathrm{HCO}_{3}^{-}+0.1$ butanol

+0.1 butanol $+1.35 \mathrm{H}_{2}+8 \mathrm{H}^{+}$

$$
\Delta \mathrm{G}^{\alpha \prime}=-325.7 \mathrm{~kJ} / \mathrm{mol} \text { substrate. }
$$

Degradation of the hydroxybutyrates, crotonate, vinylacetate, and 4-chlorobutyrate allows a nel synthesis of one mol ATP per 2 mol substrate fermented (Fig. 3). Sufficient activities of phosphate acetyl transferase and acetate kinase for ATP formation via substrate level phosphorylation were detected. The cell yields measured (3.65-4.75 g per mol substrate) agree with formation of $0.5 \mathrm{~mol}$ ATP per mol substrate, assuming a yield coefficient of about $10 \mathrm{~g}$ cell dry weight per mol ATP (Stouthamer 1979). Fermentation of lactate via the acrylate pathway is coupled with formation of only one mol ATP per three mol lactate degraded. The cell yields determined with lactate $(4.35 \mathrm{~g} / \mathrm{mol})$ and acrylate $(4.4 \mathrm{~g} / \mathrm{mol})$ are slightly higher than expected from this concept. An additional ATP gain by electron transport phosphorylation has been proposed for alanine degradation by Megasphaera elsdenii (Anderson and Wood 1969), but was never proven.

\section{Taxonomy}

The new isolate described in this study, strain LuHBu1, is an obligately anaerobic spore-forming rod and has therefore to be assigned to the genus Clostridizm (Cato et al. 1986). The cells stained gram-negative, however, it is known that some species of the genus Clostridium stain gram-variable to gram-negative (Cato et al. 1986). Strain LuHBu1 fermented fructose via a butyrate-butanol fermentation similar to C. butylicum or C. acetobutylicum (Davies and Stephenson 1941), and lactate to acetate and propionate simitar to C. propionicum (Cardon and Barker 1947). The guanine-plus-cytosine content of the DNA of strain LuHBu1 was $32.0 \pm 1.0 \%$, and was similar to that 
of C. propionicum $(35.3 \pm 0.5 \%)$. Growth tests revealed that C.propionicum cannot grow with 2- or 4-bydroxybutyrate as substrate. To our knowledge there is no species of the genus Clostridium described so far that combines all major fermentation patterns of our new isolate, and therefore a new species, $C$. homopropionicum is established.

\section{Species description}

C. ho.mo.pro.pi.oni.cum sp. nov. homoios, Gr adj. similar; acidum propionicum, M. L. n. propionic acid; homopropionicum referring to metabolic analogy to C.propionicum.

Straight rods with rounded ends, $1.2-1.5 \times 5.5-$ $10 \mu \mathrm{m}$ in size, single or in pairs. Motile in young cultures by peritrichously inserted flagella. Spherical spores formed terminally to subterminally in ageing cultures, preferentially after growth with pyruvate or lactate, or in agar medium. Dark inclusions formed after growth with lactate. Strictly anaerobic chemoorganotroph. Fructose fermented to acetate, butyrate, butanol, and $\mathrm{H}_{2}$. 2-, 3-, and 4-hydroxybutyrate, 4-chlorobutyrate, crotonate, vinylacetate and pyruvate fermented to acetate and butyrate. Lactate and acrylate fermented to acetate and propionate. No growth with glucose, arabinose, xylose, ethanol, ethanol + acetate, glycerol, 2-aminobutyrate, 4-aminobutyrate, $\alpha$-alanine, $\beta$-alanine, $\beta$-hydroxypropionate, serine, aspartate, phenylalanine, malate, fumarate, succinate, mandelatc, glycolate, ethylene glycol, trimethoxybenzoate, acetoin, or $\mathrm{H}_{2} / \mathrm{CO}_{2}$. Gelatin is not hydrolyzed.

Nitrate, nitrite, sulfite, sulfur, or thiosulfate not reduced. Fixation of molecular nitrogen. Optimal growth only in freshwater medium. Total growth inhibition at $1 \% \mathrm{NaCl} .50 \mathrm{mM}$ phosphate did not inhibit growth.

Selective enrichment in freshwater medium with 2-hydroxybutyrate as substrate. $\mathrm{pH}$-range: $5.6-8.3$, temperature optimum at $37^{\circ} \mathrm{C}$. No cytochromes detectable. DNA base ratio: $32.0 \pm 1.0 \%$ guanine plus cytosine (thermal denaturation).

Habitats: anoxic digestor sludge. Type strain: LuHBu1, DSM 5847, deposited at: Deutsche Sammlung für Mikroorganismen, Braunschweig.

Acknowledgement. We thank Prof. W. Buckel for helpful discussions and Dr. J. L. Tholozan for a sample of his propionate-degrading enrichment culture and of anaerobic digester sludge.

\section{References}

Anderson RL, Wood WA (1969) Carbohydratc metabolism in microorganısms. Annu Rev Microbiol $23: 539-578$

Bartholomew JW (1962) Variables influencing results and the precise definition of steps in grand staining as a means of standardizing the results obtained. Stain Technology $37: 139-155$

Bergmeyer IIU (1974) Methoden der enzymatischen Analyse, 3rd edn. Verlag Chemie, Weinheim, FRG

Blenden DC, Goldberg HS (1965) Silver impregnation stain for Leptospira and flagella. J Bacteriol $89: 899-900$
Cardon BP, Barker HA (1947) Amino acid fermentation by Clostridium propionicum and Diplococeus glycinophilus. Arch Biochem Biophys 12:165-180

Cato EP, George WL, Finegold SM (1986) Endospore-forming gram-positive rods and cocci. Genus Chostridam. In: Sneath PHA, Mair NS. Sharpe MR, Holt JG (eds) Bergey's manual of systematic bacteriology, vol 2. Williams and Wilkins, Baltimore, pp $1141-1200$

Cord-Ruwisch R (1985) A quick method for the determination of dissolved and precipitated sulfides in cultures of sulfate-reducing bacteria. J Microbiol Methods 4:33-36

Davies R, Stephenson M (1941) Studies on the acetone-butyl alcohol fermentation. I. Nutritional and other factors involved in the preparation of active suspensions of Clostridium acetobutylicum. Biochem J 35:1320-1331

De Ley J (1970) Reexamination of the association between melting point, buoyant density, and the chemical base composition of deoxyribonucleic acid. J Bacteriol 101: $738-754$

Drews G (1983) Mikrobiologisches Praktikum, 4. Aufl. Springer, Berlin Heidelberg New York

Gregersen T (1978) Rapid method for distunction of Gram-negative from Gram-positive bacteria. Eur J Appl Microbiol Biotechnol $5: 123-127$

Hardman JK, Stadtman TC (1963) Metabolism of $\omega$-aninoacids. IV. $\eta$-aminobutyrate fermentation by cell-free cxtracts of Clostridium aminobutyricum. J Biol Chem 238:2088-2093

Hollaus F, Sleytr UB (1972) On the taxonomy and fine structure of some hyperthetmophilic saccharolytic clostridia. Arch Microbiol 86:129-146

Houwen FP, Dijkema C, Schoenmakers CHH, Stams AJM, Zehndet AJB (1987) ${ }^{13}$ C-NMR study of propionate degradation by methanogenic coculture. FEMS Microbiol Lett $41: 269-$ 274

Koch M, Dolfing J, Wuhrmann K, Zehnder AJB (1983) Pathways of propionate degradation by enriched methanogenic cultures. Appl Environ Microbiol 45:1411 - 1414

Law JH, Slepecky RA (1961) Assay of poly- $\beta$-hydroxybutyric acid. J Bacteriol 82:33-36

Marmur $J$ (1961) A procedure for the iselation of deoxyribonucleic acid from microorganisms. J Mol Biol 3:208-218

Matthies C, Mayer F. Schink B (1989) Fermentative degradation of putrescine by new strictly anaerobic bacteria. Arch Microbiol $151: 498-505$

Molinari R, Lara FJS (1960) The lacte dehydrogenase of Propionibacterium pentosaceum. Biocham J 75:57-65

Pfennig N (1978) Rhodocyclus purpureus gen. nov. and sp. nov. a ring shaped, vitamin $B_{12}$-requiring member of the family Rhodospirillaceae. Int J Syst Bacteriol 28:283-288

Platen H, Schink B (1987) Mcihanogenic degradation of acetone by an enrichment culture. Arch Mictobiol 149: 136-141

Procházková L (1959) Bestimmung der Nitrate im Wasser. Z Anal Chem 167:254-260

Schink B (1985) Mechanisms and kineties of succinate and proplonate degradation in anoxic freslawater sediments and scwage sludge. I Gen Microbiol $131: 643-650$

Schwciger $G$, Buckel W (1984) Studies on the dehydration of $(R)$ 2-hydroxyglutarate in Acidaminococcus fermentans. A radical mechanism? Arch Microbiol 139:167-173

Stams A.M, Krcmer DR. Nicolay K, Weenk GH, Hansen TA (1984) Pathway of propionate formation in Desulfobulbus propunicus. Arch Microbiol 139:167-173

Stieb M, Schink B (1984) A new 3-hydroxybutyrate fermenting anaetobe, Ilyohacter polytropus, gen. nov. sp. nov., possessing various fermentation pathways. Arch Microbiol 140:139 -- 146

Stouthamet $A G$ (1979) The search for a correlation between theoretical and experimental growth yields. In: Quayle JR (ed) International revicw of biochemistry, microbial biochemistry, vol 21. Universily Park Press, Baltimore, pp 1-47

Thauer RK, Jungermann K, Decker K (1977) Energy conservation in chemotrophic anaerobic bacteria. Bacteriol Rev 41:100180 
Tholozan IL, Samain E, Grivet JP, Moletta R., Dubourguier HC, Albagnac $G$ (1988) Reductive carboxylation of propionate to butyrate in methanogenic ecosystems. Appl Environ Microbiol 54:441-445

Tschecl A, Pfennig N (1984) Growth yield increase linked to caffeate reduction in Acetobacteritm woodii. Arch Microbiol $137: 163-167$

Widdel F, Pfennig $N$ (1981) Studies on dissimilatory sulfatereducing bacteria that decompose fatty acids. I. Isolation of a new sulfatereducer enriched with acetate from saline enviromments. De scription of Desulfobacter postgatei gen. nov. sp. nov. Arch Microbiol 129:395-400
Widdel F, Kohring GW, Mayer F (1983) Studies on dissimilatary sulfate-reducing bacteria that decompose fatty acids. III. Characterization of the filamentous gliding Desulfonema limicala gen. nov. $\mathrm{sp}$. nov., and Desulfonema magnum sp. nov. Arch Microbiol 134:286-294

Zamenhoff S (1957) Preparation and assay of deoxyribonucleic acid from animal tissue. In: Colowick SP, Kaplan NO (eds) Methods in enzymology, vol 3. Academic Press, New York, pp 696-704 Zehnder AJB, Ingvorsen K, Marti T (1982) Microbiology of methane bacteria. In: Hughes DE, Stafford DA, Wheatley BI, Baader $W$, Lettinga $G$, Nyns $E J$, Verstraete $W$ (eds) Anderobic digestion. Ilsevier Biomedical Press, Amsterdam, pp 45-68 